\title{
ECONOMIC ACTIVITY AS ONE OF THE SMART AND SUSTAINABLE DEVELOPMENT TRENDS IN RURAL TERRITORIES
}

\author{
Baiba Rivza, PhD hab.'; Maiga Kruzmetra, Senior Researcher²
}

Faculty of Economics, Latvia University of Life Sciences and Technology

\begin{abstract}
Rural territory is an important part of the community's living space, moreover, it is a living space for sustainable and smart development. With the growing public demand for a healthy living environment and healthy food, the role of rural territory as a living space for community and the necessity to maintain its sustainable development is increasing. However, the sustainability of rural territories as a living space will be preserved only when residents are ready for changes and if national institutions and local governments are promoting trends politically and practically. The aim of the research: to examine economic activity in the rural areas of Latvia with regard to promoting the sustainable and smart development direction during 2009-2016 and to assess the results achieved. An analysis of the information on entrepreneurship expansion used in the research allows making a number of conclusions. Even though Latvia has the lowest competitiveness rating among Poland, Lithuania, Latvia and Estonia, at the same time, it is characterised by the highest growth rates and small distances among these countries. The reduction of these differences was significantly influenced by economic activity expansion, including the knowledge economy segment in Latvia. The growth of the economy in the rural territories surpasses the growth rates in major cities. The rural space has confirmed its suitability for the innovative functioning and growth of the economy.
\end{abstract}

Keywords: rural territories; sustainable development; economic activities

JEL codes: O4, P17

\section{INTRODUCTION}

Issues pertaining to rural areas as a space and to sustainable smart development in the rural areas are a set of challenges to be tackled in the 21 st century. Rural areas as a necessary component of living space for the population is an increasing focus both in official documents of various EU institutions and in research investigations. Both the documents (Council of Europe, 2017; ESPON 2018) and the research papers
(Jordan ed., 2017; Rönkkö and Aarrevaara, 2017) stress the necessity to enhance and maintain the viability of rural areas. The status of rural viability shall also constitute the theoretical background of this research.

In the characteristics of viability, an important position is given to economic activity. The health of the local economy is regarded as one of the key factors for maintaining the viability of a community in a populated place (Grigsby, 2001; Scott, 2010). Creative and

${ }^{1}$ Corresponding author: Svetes 18, LV-3001 Jelgava, Latvia, baiba.rivza@1lu.lv

${ }^{2}$ Corresponding author: Svetes 18, LV-3001 Jelgava, Latvia, maiga.kruzmetra@1lu.lv 
diversified economic activities have to be fostered in order to ensure employment and therefore retain population in the particular territory. At present, Latvia lags behind such Baltic Sea eastern coast countries as Poland, Lithuania and Estonia, even though the countries developed in a similar way during the last century. For this reason, the authors, first of all, focused on a comparative analysis of the economic competitiveness of the mentioned countries. However, the key task of the research is to examine economic growth in the rural areas of Latvia with regard to promoting the sustainable and smart development direction during 2009-2016 and to assess the results achieved.

The EU has integrated economic sectors and strong local economies (Rural Coalition, 2010; Naldi et al., 2015). As regards economic development, the following priorities have been set: developing an economy based on knowledge and innovation, promoting a more resource efficient, greener and more competitive economy and fostering a high-employment economy delivering economic, social and territorial cohesion (European Commission, 2010). As Latvia joined the European Union in 2004 and integrated into the OECD country group in 2016, the formation and development of economy has become a practical task and an object of research according to economic competitiveness indicators (Global Competitiveness Index).

The Latvian Rural Development Policy for 2014-2020 (Ukrainian Ministry of Agriculture, 2015) has been used as the methodological base of the research. The data were processed by quantitative and qualitative statistical analysis, as well as the grouping methods. As information sources for the analysis was used: the Global Competitiveness Index (World Economic Forum, 2010, 2016); the Eurostat classification of industries (NACE Rev. 2, 2008); LURSOFT and CSB data on changes in the national economy; survey results on the contribution of 'growth agents' to the sustainable and smart development of rural areas.

\section{RESULTS AND DISCUSSION}

\section{Promotion of economic growth in Latvia as an urgent priority}

Since 2004 when Latvia became a member state of the EU with a very open economy, the competitiveness of the national economy under the free market economy has become an important indicator showing the progress of the society towards smart growth. A comparison of the competitiveness index (World Economic Forum, 2010, 2016) of the four Baltic Sea eastern coast countries made in the research led to two considerable findings.

First, Latvia was ranked the lowest and had the lowest score according to both the report 2010/2011 and the report 2016/2017 - Estonia dominated, while Poland and Lithuania exchanged their places in the ranking. Nevertheless, Latvia demonstrated the fastest changes in terms of competitiveness, and a difference between the highest and lowest index values in the period of analysis decreased. The ranking of competitiveness of the economies of Estonia and Poland climbed three places in the index and that of Lithuania - 12 places, while Latvia improved its performance by 21 places. This, of course, is a positive result.

Table 1. Changes in the competitiveness performance of the selected countries

\begin{tabular}{|l|c|c|c|c|c|c|c|c|}
\hline \multirow{2}{*}{ Item } & \multicolumn{2}{|c|}{ Estonia } & \multicolumn{2}{c|}{ Lithuania } & \multicolumn{2}{c|}{ Latvia } & \multicolumn{2}{c|}{ Poland } \\
\cline { 2 - 10 } & rank & score & rank & score & rank & score & rank & score \\
\hline $2010 / 2011$ & $\mathbf{3 3}$ & 4.61 & $\mathbf{4 7}$ & 4.38 & $\mathbf{7 0}$ & 4.14 & $\mathbf{3 9}$ & 4.51 \\
\hline $2016 / 2017$ & $\mathbf{3 0}$ & 4.78 & $\mathbf{3 5}$ & 4.6 & $\mathbf{4 9}$ & 4.45 & $\mathbf{3 6}$ & 4.56 \\
\hline Growth & $\mathbf{+ 3}$ & +0.17 & $\mathbf{+ 1 2}$ & +0.22 & $\mathbf{+ 2 1}$ & +0.31 & $+\mathbf{3}$ & +0.05 \\
\hline
\end{tabular}

Source: Global Competitiveness Index 2010/2011;2016/2017. 


\section{Economic activity expansion in Latvia in the period 2009-2016}

The increase in competitiveness, according to the calculations, could occur owing to fast entrepreneurship expansion in the period of analysis. The number of economically active enterprises almost doubled; their net turnover rose by half, even though the number of employees increased by less than $20 \%$. als, which indicated innovative changes in economic activity.

\section{Economic activity rates are higher in rural areas than in cities of national significance}

Since the viability of rural space is an urgent problem in the entire European Union in order to shape a vital rural area and to contribute to smart growth there, the

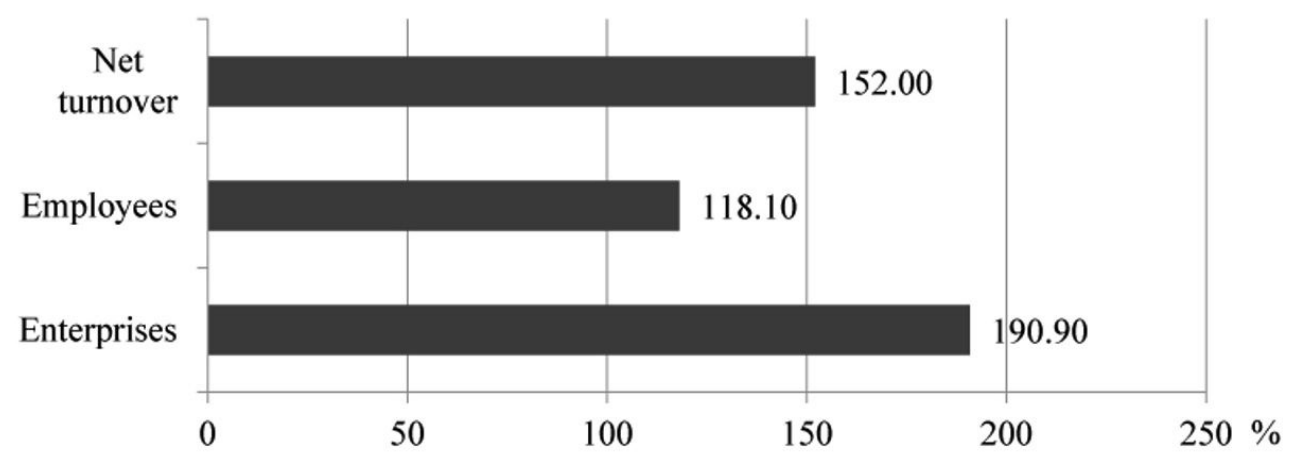

Figure 1. Entrepreneurship expansion in Latvia in the period 2009-2016

Source: LURSOFT data 2009/2016.

The changes could be viewed from two perspectives. On the one hand, the expansion of economic activity was not so significant to reduce the low competitiveness of the national economy of Latvia among the selected countries. On the other hand, modernisation indications could be observed in economic growth processes, as an increase in the net turnover exceeded that in the number of employed individu- authors focused on economic growth in the rural space of Latvia that was comprised of 110 rural municipalities with $49.2 \%$ of the total population. A comparison of growth in economic activity in nine cities of national significance and in the 110 rural municipalities preformed in the research revealed that the economic development processes occurred at higher rates in the rural space than in the major cities.

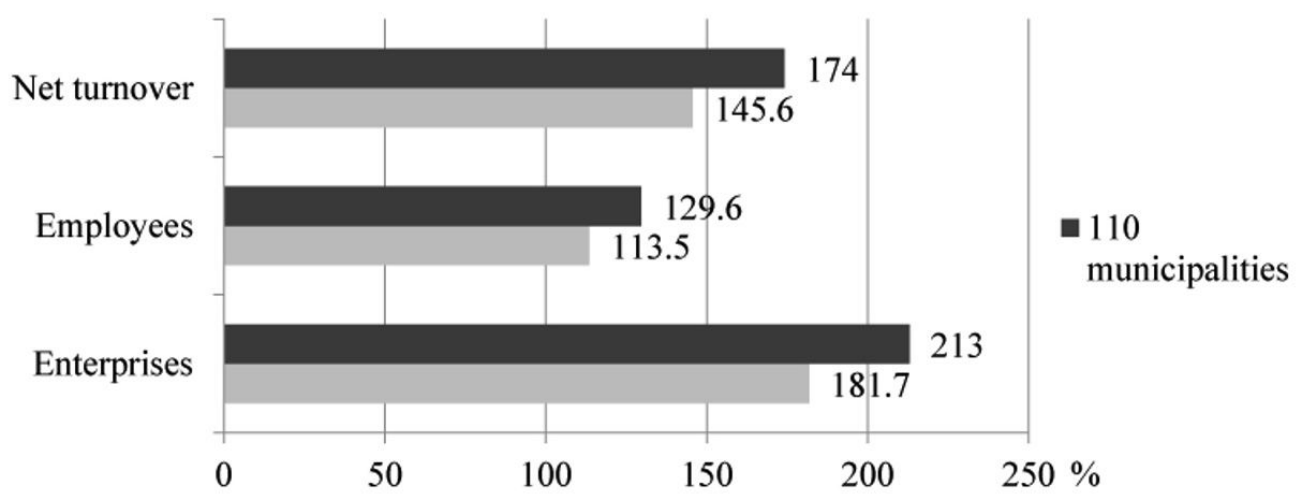

Figure 2. Entrepreneurial performance in the cities and rural municipalities 
Entrepreneurial performance represents increases in the number of enterprises, employed individuals and net turnover. The analysis revealed that the rural areas as a living environment did not increasingly lag behind the cities - they gradually reduced the economic gaps with the cities, which gives an opportunity for the rural areas to strengthen their viability.

\section{Deeper insight into the development of the rural space indicates differentiation}

The comparison of growth in economic activity between the rural space and cities of Latvia deals with only averages. Average indicators, on the one hand, are informative, while on the other hand, they are 'misleading', i.e. too generalised. For this reason, the authors performed a detailed analysis of economic activity in the rural municipalities. Three statistical indicators (number of enterprises, number of employees and total net turnover) employed to analyse the situation with entrepreneurship allowed grouping the municipalities. In the result, an analysis of the data for 2016 identified three groups. The first group represented municipalities with high entrepreneurial performance (three municipalities), the second one (23 municipalities) had moderate entrepreneurial performance, while the third group performed the worst - it had the smallest number of enterprises, the lowest employment and the lowest net turnover (84 municipalities).

The second and third group municipalities were located in all the statistical regions of Latvia. Three municipalities where knowledge intensive services dominated in economic activity, of course, were located in Pieriga region. This region also had the largest number of moderately performing municipalities. At the same time, more than half of Pieriga region's municipalities performed poorly. The processed data lead to a conclusion that the proximity of the capital city affects the processes, yet it is not the only factor affecting entrepreneurship expansion, which is confirmed by the locations of moderately performing municipalities in the rural areas of Latvia.

Explicit distinctions among the groups of municipalities could be identified if analysing the groups by kind of economic activity. High entrepreneurial performance was specific to the municipalities where knowledge-based economic activities (HT, MHT and KIS) dominated, whereas low entrepreneurial performance was observed in the municipalities in which agriculture and forestry as well as low technology manufacturing enterprises made up relatively higher proportions.

The processed data allow convincingly drawing up at least three conclusions. First, the data confirm the need for growth in the knowledge-based economy in order to raise the quality of the national economy and consequently enhance the competitiveness of it. Second, the data also confirm the need for associating agriculture and forestry with innovative technologies, so that these kinds of economic activity shift from the primary sector to the secondary sector by using as modern technologies as possible. This could pave the way for an increase in the competitiveness of the bioeconomy in particular in both the EU and the global markets.

Table 2. Geographic locations of the three groups of municipalities

\begin{tabular}{|l|c|c|c|c|}
\hline \multirow{2}{*}{ Region } & \multirow{2}{*}{$\begin{array}{c}\text { Number } \\
\text { of municipalities }\end{array}$} & low & average & high \\
\cline { 3 - 5 } & 28 & $15-53.6$ & $10-35.7$ & $3-10.7$ \\
\hline Pieriga & 25 & $21-84.0$ & $4-16.0$ & 0 \\
\hline Vidzeme & 20 & $15-75.0$ & $5-25.0$ & 0 \\
\hline Zemgale & 18 & $15-83.3$ & $3-16.7$ & 0 \\
\hline Kurzeme & 19 & $18-94.7$ & $1-5.3$ & 0 \\
\hline Latgale & 110 & $84-76.4$ & $23-20.9$ & $3-2.7$ \\
\hline Rural space & 10 &
\end{tabular}

Source: authors' calculations based on LURSOFT data for 2016. 
Proceedings of the 2018 International Scientific Conference 'Economic Sciences for Agribusiness and Rural Economy' No 1, Warsaw, 7-8 June 2018, pp. 48-54

Table 3. Kinds of economic activity of total broken down by group of municipalities

\begin{tabular}{|c|c|c|c|}
\hline \multirow{3}{*}{ Kind of economic activity } & \multicolumn{3}{|c|}{ Municipality group performance } \\
\hline & high & moderate & low \\
\hline & \multicolumn{3}{|c|}{$\%$} \\
\hline (F) Construction & 9.86 & 10.4 & 9.0 \\
\hline (B) Quarrying & 0.39 & 5.77 & 0.7 \\
\hline (A) Agriculture, forestry, fisheries & 2.0 & 6.98 & 22.2 \\
\hline (E) Water supply, sewerage, waste management & 0.5 & 0.54 & 0.51 \\
\hline (D) Electricity, gas supply & 0.44 & 0.73 & 1.1 \\
\hline (C) High-technology & 0.18 & 0.19 & 0.1 \\
\hline (C) Medium-high-technology & 1.0 & 0.73 & 0.8 \\
\hline (C) Medium-low-technology & 2.8 & 2.7 & 2.3 \\
\hline (C) Low technology & 4.5 & 7.1 & 8.7 \\
\hline Knowledge-intensive services (KIS) & 28.8 & 20.3 & 15.4 \\
\hline Less knowledge-intensive services (LKIS) & 49.5 & 44.5 & 39.2 \\
\hline Total & 100 & 100 & 100 \\
\hline Agriculture, forestry, fisheries & 2.0 & 6.98 & 22.2 \\
\hline Manufacturing & 8.48 & 10.72 & $\mathbf{1 1 . 9}$ \\
\hline HT and MHT group & 1.18 & 0.92 & 0.9 \\
\hline Knowledge intensive services & 28.8 & 20.3 & 15.4 \\
\hline
\end{tabular}

Source: authors' calculations based on LURSOFT data for 2016 .

Third, the rural space is a favourable environment for the expansion of knowledge intensive services, which is observed even in the group of poorly performing municipalities, as only e-environment infrastructure and competent personnel are required for it.

Traditional economic success in the rural space is associated not only with its proximity to cities but also a higher population density (number of inhabitants per $1 \mathrm{~km}^{2}$ ). The calculations performed in the research call into question the dominance of this factor. If municipalities with similar population densities belong to both the group of well performing municipalities (Kekava municipality -83.4 inhabitants per $1 \mathrm{~km}^{2}$ ) and the group of poorly performing municipalities (Carnikava municipality -86.1 inhabitants per $1 \mathrm{~km}^{2}$ ) and if municipalities with a population density of $11-$ 12 people per $1 \mathrm{~km}^{2}$ belong to the group of moderately performing municipalities, other factors affecting smart development have to be sought.
A survey of experts, which was based on the same methodology, conducted in Latvia, Lithuania and Poland in 2016 indicated such factors (Rivza et al., 2017). As a positive factor, the experts mentioned the skill of national institutions and local governments to acquire and use European Union funding. However, the experts referred to the following significant shortcomings in the activities of performance agents:

- the legal framework and the tax system that regulate entrepreneurship and ensure stability (national institutions);

- insufficient cooperation with local residents and entrepreneurs (local governments);

- insufficient readiness of residents themselves for economic collaboration and continuous learning in order to comprehend and follow on-going changes in economic activity (residents of municipalities). 
It is possible that this particular set of factors specified by the experts can explain the way how to achieve an average development level in the municipalities located quite far away from the capital city and the cities of national significance and in the areas where the population density is quite low. Therefore, a focus has to be placed on the factors promoting growth, the competences of governance institutions in managing the processes entrusted to them have to be built up and the knowledge and skills of rural residents have to be enhanced under the new economic conditions caused by the beginning of a new economic growth stage. Knowledge and skills and their territorial transfer are still an urgent problem to be tackled in order to contribute to the sustainable viability of rural space (Council of Europe, 2017).

\section{CONCLUSIONS}

Economic development occurred in Latvia in the period of analysis - the number of enterprises and the number of employed individuals rose and the net turnover of the enterprises increased as well. These processes developed faster in the rural space than in the cities of national significance. This means that vitality prevailed in the rural space of Latvia, which ensured this change.

A question remains whether this vitality is sufficient to strengthen the viability of rural space in a long-term if populations decrease in the rural space in all the EU Member States, the ageing of the populations is observed and poor living conditions exist there. According to the survey of experts conducted by the research, to date all opportunities have not been used to raise local community capacity in order that local governments and local residents as well as the local residents themselves could closely cooperate in order to enhance their living space based on innovative ideas and modern activities. Vitality in the rural space is observed in limited areas; therefore, continuing reducing disparities between the cities and the rural territories as well as among the rural regions and the rural municipalities in particular becomes an urgent priority. Opportunities and the most effective ways to reduce the disparities, the necessary skills and knowledge in particular and the ways of learning the knowledge are important priorities of further research.

\section{REFERENCES}

1. Council of Europe (2017). A better future for Europe's rural areas. In: Congress of Local and Regional Authorities. Report. Retrieved from: https://rm.coe.int/a-better-future-for-europe-s-rural-areas-governance-committee-rapporte/168074b728 [Accessed 19.10.2017].

2. ESPON (2018). Policy Brief: The territorial dimension of future policies. Retrieved from: https://www.espon. eu/future-policies.

3. European Commission (2010). Europe 2020: a European Strategy for Smart, Sustainable and Inclusive Growth. Brussels. Retrieved from: http://ec.europa. eu/eu2020/pdf/COMPLETENBARROSO007-Europe2020-EN version.pdf.

4. European Commission (2015). Rural Development 2014-2020. Retrieved from: https://ec.europa.eu/agriculture/rural-development-2014-2020_en.

5. Grigsby, W.J. (2001). Community vitality: Some conceptual considerations. Rural Development Paper No 6. The Northeast Regional Center for Rural Development, The Pennsylvania State University. Retrieved from: http://aese.psu.edu/nercrd/publications/rdp/rdp6.pdf.

6. Jordan, P. (ed.) (2017). New Developments IN the Rural Space of Central and South-East Europe. In: Proceedings of the meeting of the Working Group on Central Europe in conjunction with the German Congress of Geography, Berlin 30.09.2015.

7. NACE Rev. 2 (2008). Statistical Classification of Economic Activities in the European Union. Retrieved from: http://ec.europa.eu/eurostat/web/products-manuals-and-guidelines/-/KS-RA-07-015.

8. Naldi, L., Nilsson, P., Westlund, H., Wixe, S. (2015). What is Smart Rural Development? Journal of Rural Studies, 40, pp. 90-101.

9. OECD (2005). The Measurement of Scientific, Technological and Innovation Actions. 3rd ed. Retrieved from: http://www.oecd-ilibrary.org/science-and-technology/ the-measurement-of-scientific-technological-and-innovation-activities_24132764 [Accessed 26.05.2017].

10. Rivza, B., Kruzmetra M., Grinberga-Zalite, G., Wojewodzka-Wiewiorska, A., Jasaitis, J. (2017). Expertlevel Comprehensive Analysis of the Viability of Rural Areas in the Baltic Sea East Coast States. In: Proceedings of SGEM 2017 Conference. Vol. 17, pp. 393-399. DOI: $10.5593 /$ SGEM2017/53/S21.049 
11. Rönkkö, E., Aarrevaara, E. (2017). Towards Strengthsbased Planning Strategies for Rural Localities in Finland. European Countryside, 9 (3), pp. 397-415. DOI: 10.1515/euco-2017-0024

12. Rurality Environment Development (2016). Making Europe Grow With its Rural Territories. Contribution to a European Rural Agenda post 2020. Retrieved from: http://doc.ruraleurope.org/public/Web/Communication/RED/EN/RED-Com2030-E.pdf.

13. Scott, K. (2010). Community Vitality. A report of the Canadian index of wellbeing. Canadian Council on Social Development (CCSD). Retrieved from: http:// www.unesco.org/fileadmin/MULTIMEDIA/HQ/CLT/ pdf/communityvitalitydomainreport.pdf.

14. Rural Coalition (2010). The rural challenge: Achieving sustainable rural communities for the 21 st century. London. Retrieved from: http://www.rtpi.org.uk/me- $\mathrm{dia} / 6331 /$ the-rural-challenge-achieving-sustainable-rural-communites-for-the- 21 st-century-rural-coalition2010.pdf.

15. Ukrainian Ministry of Agriculture (2015). Latvijas lauku attîstîbas programma 2014-2020 (2015) [Rural Development Programme of Latvia 2014-2020]. Retrieved from: http://www.laukutikls.lv/nozares/lauku-telpa/ lauku-politika/latvijas-lauku-attistibas-programma.

16. World Economic Forum (2010). The Global Competitiveness Report 2010/2011. Geneva. Retrieved from: http://www3.weforum.org/docs/WEF_GlobalCompetitivenessReport_2010-11.pdf.

17. World Economic Forum (2016). The Global Competitiveness Report 2016/2017. Geneva. Retrieved from: http://www3.weforum.org/docs/GCR20162017/ 05FullReport/TheGlobalCompetitivenessReport20162017_FINAL.pdf. 